ARTIGO CIENTÍFICO

\title{
Seleção assistida no melhoramento da soja destinada à alimentação humana no
} Estado do Tocantins

\section{Assisted selection in the improvement of soy for human consumption in the State of Tocantins}

\author{
Aristoteles Capone $^{* 1}$, Alex Sandro Dario ${ }^{2}$, Raimundo Wagner de Souza Aguiar ${ }^{3}$, Rodrigo Ribeiro Fidelis ${ }^{3}$, Hélio Bandeira \\ Barros $^{3}$
}

\begin{abstract}
Resumo: A soja na alimentação humana apresenta vários benefícios à saúde, mas encontra resistência ao seu consumo pelos ocidentais devido o sabor causado pelas enzimas lipoxigenases. Objetivou-se com o estudo selecionar híbridos de soja TN (Triplo Nulo), em uma população do quarto ciclo de autofecundação (F4) através de técnicas que utilizam marcadores moleculares. $\mathrm{O}$ experimento foi conduzido na área experimental da Universidade Federal do Tocantins Campus de Gurupi Tocantins. Foram realizadas hibridações entre progenitores de soja adaptados ao Tocantins e TN. Obteve-se a população F1 em casa de vegetação, F2, F3 e F4 foram plantadas a campo, na geração F4 houve seleção de híbridos superiores para análise de DNA, com a finalidade de identificar híbridos com a característica ausência completa das Lox2 e Lox3. Foram selecionados cento e setenta e um híbridos, fez-se extração de DNA e PCR de todos. Concluiu que, a maior porcentagem de híbridos TN foi obtida no cruzamento BRSMG 790A (TN) X GB874. Os primers amplificadores das regiões Lox2 e Lox3 confirmaram como ferramenta essencial em programa de melhoramento genético de soja para alimentação humana. Foram selecionados 34 híbridos TN com características agronômicas desejadas.
\end{abstract}

Palavras-chave: Glycine max; Hereditariedade; Melhor Sabor.

\begin{abstract}
Soy in human food has several health benefits, but finds resistance to its consumption by the western ones due to the flavor caused by the lipoxygenases enzymes. The objective of this study was to select soybean TN (Triple Null) hybrids in a population of the fourth self-fertilization cycle (F4) using techniques that use molecular markers. The experiment was conducted in the experimental area of the Federal University of Tocantins Campus Gurupi - TO. Hybridizations between soybean progenitors adapted to Tocantins and TN were performed. Obtained the F1 population in the greenhouse, F2, F3 and F4 were planted in the field, in the F4 generation was selection of superior hybrid for DNA analysis in order to identify hybrids with the trait complete absence of Lox 2 and 3. We selected one hundred seventy-one hybrid, made up of DNA extraction and PCR of all. It was concluded that the highest percentage of TN hybrids was obtained at the intersection BRSMG 790A (TN) X GB874. Lox2 and Lox3 amplification primers confirmed as an essential tool in a soybean breeding program for human consumption. We selected $34 \mathrm{TN}$ hybrids with the desired agronomic characteristics.
\end{abstract}

Key words: Glycine max; Heredity; Better Flavor.

\footnotetext{
*Autor para correspondência

Recebido para publicação em 23/02/2017; aprovado em 27/06/2017

${ }^{1}$ Engenheiro Agrônomo, Doutor. Universidade Federal do Tocantins, Departamento de Fitotecnia, Campus Universitário de Gurupi. Caixa-Postal 66, 77402-

970, Gurupi, TO, Brasil. (63) 3311-3523 aristotelescapone@ hotmail.com

${ }^{2}$ Graduando em Agronomia pela Universidade Federal do Tocantins, Departamento de Fitotecnia, Campus Universitário de Gurupi. Caixa-Postal 66, 77402970, Gurupi, TO, Brasil. alexsandrodario@gmail.com

${ }^{3}$ Engenheiros-Agrônomos, Doutores, Professores Adjunto. Universidade Federal do Tocantins, Departamento de Fitotecnia, Campus Universitário de Gurupi. Caixa-Postal 66, 77402-970, Gurupi, TO, Brasil.rwsa@mail.uft.edu.br, fidelisrr@pq.cnpq.br, barroshb@pq.cnpq.br
} 


\section{INTRODUÇÃO}

A soja possui propriedades funcionais (nutracêuticas) decorrentes não somente das proteínas, mas também de outros constituintes químicos do grão (isoflavonas), com numerosas alegações ligando seus efeitos à promoção da saúde, como prevenção e tratamento de doenças cardiovasculares, câncer, osteoporose e sintomas da menopausa, além de ser a única alternativa para as pessoas com intolerância à lactose (DUFFY et al., 2007; DANTAS et al., 2010; SILVA et al., 2012; JUHÁSZ et al., 2014).

Também há diferenciação nutricional e funcional nas diferentes cores de tegumento, exemplo grãos preto. Estes são associados a uma gama de efeitos benéficos à saúde, como antimutagênicos, propriedades anti-inflamatórias, inibição da lipoproteína de baixa densidade, oxidação e redução de danos ao DNA e outras varias características e potencialidades a serem estudadas (ASTADI et al., 2009; OLIVEIRA et al., 2010; WANG et al., 2010).

Mesmo apresentando vários benefícios a saúde humana, a soja é pouca consumida pelos ocidentais, devido ao sabor feijão cru ou "beany flavor" (SILVA et al., 2009a), existem processos para a redução destes sabores, como tratamento térmico. Estudos realizados por Machado et al. (2008), consideram o tratamento térmico como um determinante da qualidade proteica, pois pode inibir fatores antinutricionais da soja convencional e alterar estruturas das proteínas, elevando a digestibilidade. Nos estudos realizado por Silva et al. (2010), concluíram que o tratamento térmico interferi na qualidade proteica de novos cultivares de soja alimentação humana, ocorrendo melhora na qualidade proteica de farinhas com casca.

Com base nesses resultados positivos, o tratamento térmico vem ser um aliado ao uso da soja alimentação humana, combinação esta, que pode levar ao aumento do consumo no Brasil e expansão em novas fronteiras agrícolas, também o que se torna indispensável é a eliminação genética das lipoxigenases com a confecção de cultivares TN (Triplo Nulo), considerada mais eficiente forma de reduzir o sabor indesejável, também o método mais viável devido a hereditariedade, além de manter as propriedades funcionais da soja.

As enzimas lipoxigenases estão presentes em grãos de soja na forma de três isoenzimas: Lox1, Lox2 e Lox3. Elas são codificadas por três genes dominantes, são herdados de modo mendeliano. Os locos para Lox1 e Lox2 estão mapeados no mesmo grupo de ligação, a Lox3 é independente (KIM et al., 2006). Desta forma para a retirada destas três enzimas são usadas inúmeras técnicas no processo de melhoramento de plantas, do convencional (cruzamentos em forma de dialelos) ao uso de biotecnologias (marcadores moleculares). $\mathrm{Na}$ atualidade temos como exemplo os marcadores SNP (single nucleotide polymorphism), que são abundantes, dessa forma aumentando a possibilidade de sucesso em diversas aplicações (CHOI et al., 2007).

Um dos motivos da expansão do cultivo da soja tipo alimento ser limitado no Brasil é, a pouca disponibilidade de cultivares adaptados às diversas regiões do país, dentre elas o Cerrado, quando cultivares de soja destinados a alimentação humana são introduzidas em regiões de menores latitudes (Tocantins) reduzem o ciclo, apresentam baixa estatura e rendimento (SANTOS et al., 2011), assim seu cultivo fica restrito a regiões de lançamento.
Neste contexto, o objetivo do presente estudo foi, selecionar plantas de soja TN em uma população do quarto ciclo de autofecundação (F4) através de marcadores moleculares.

\section{MATERIAL E MÉTODOS}

A pesquisa foi conduzida nos anos 2012, 2013 e 2014, na Universidade Federal do Tocantins, Campus Universitário de Gurupi, Estado do Tocantins, localizada a $11^{\circ} 43^{\prime}$ de latitude Sul e $49^{\circ} 04^{\prime}$ de longitude Oeste e altitude de $280 \mathrm{~m}$, temperaturas média variando de 16 a $35^{\circ} \mathrm{C}$, solo é do tipo Latossolo Vermelho Amarelo distrófico.

As análises químicas e físicas do solo apresentaram as seguintes características: $\mathrm{pH}-\mathrm{H}_{2} \mathrm{O}=5,6 ; \mathrm{Al}+\mathrm{H}=2,6 \mathrm{cmol}_{\mathrm{c}}$ $\mathrm{dm}-3 ; \mathrm{Ca}_{2+}+\mathrm{Mg}_{2+}=2,6$ cmolc dm $-3_{\mathrm{c}} \mathrm{K}_{+}=70 \mathrm{mg} / \mathrm{dm}_{3} ; \mathrm{P}=3,5$ $\mathrm{mg} / \mathrm{dm}_{3} ; \mathrm{S}=11,8 \mathrm{mg} / \mathrm{dm}_{3} ; \mathrm{SB}=3,0 \mathrm{cmol}_{\mathrm{c}} \mathrm{dm}-3 ; \mathrm{CTC}(\mathrm{T})=$ $5,6 \mathrm{cmol}_{\mathrm{c}} \mathrm{dm}-3$; matéria orgânica: $2,2 \%$; areia $=71 \%$; silte $=$ $5 \%$; argila $=24 \%$ e para os micronutrientes: $\mathrm{Zn}=0,9$ $\mathrm{mg} / \mathrm{dm}_{3} ; \mathrm{Fe}=34,2 \mathrm{mg} / \mathrm{dm}_{3} ; \mathrm{Mn}=5,9 \mathrm{mg} / \mathrm{dm}_{3} ; \mathrm{Cu}=0,6$ $\mathrm{mg} / \mathrm{dm}_{3}$ e $\mathrm{B}=0,3 \mathrm{mg} / \mathrm{dm}_{3}$. Foram realizadas calagens de acordo com a necessidade da cultura. Dessecação das plantas daninhas com herbicida glifosato $2 \mathrm{~L}$ ha $^{-1}$ antes da implantação por semeadura direta. As adubações de base foram aplicadas no sulco de semeadura com $480 \mathrm{~kg} \mathrm{ha}^{-1} \mathrm{da}$ formulação 5-25-15 (NPK). Aplicação de adubos foliares quando necessários. Nos períodos de estiagem houve irrigação por aspersão com turno de rega de 3 vezes por semana. As aplicações de defensivos agrícolas no controle de pragas foram de acordo com manejo integrado de pragas.

\section{Hibridação e condução de população}

Os programas de melhoramento de soja exerceram influência marcante sobre o desenvolvimento dessa leguminosa no Brasil (VASCONCELOS et al., 2015). Um dos principais objetivos dos programas de melhoramento genético é a seleção de genótipos de soja com elevada produtividade de grãos e capacidade de adaptação ambiental, que estão aliadas com a predição dos ganhos obtidos por seleção (FARIA et al., 2007). Um método muito usado é a hibridação, que tem como finalidade aumentar a variabilidade genética, procurando introduzir característica de interesse a partir dos cruzamentos entre os indivíduos, posteriormente realiza seleção e identificação de indivíduos que reúnam os fenótipos de interesse.

Foram utilizadas quatro progenitores TN (cultivares oriundos de outras regiões do país com ausência das enzimas lipoxigenases) e oito progenitores adaptados a região sul do Estado do Tocantins (selecionados a priori pela medida de dissimilaridade pelos métodos de otimização Tocher, de Singh (1981) e de agrupamento UPGMA). Sobre os progenitores $\mathrm{TN}$ foram utilizados em especial dois, as quais foram lançadas em 2008, numa parceria Embrapa/EPAMIG/Fundação Triangulo que lançaram a cultivar BRSMG 790A, de tegumento amarelo, e, em 2010, a 'BRSMG 800A', primeira cultivar brasileira de soja de tegumento marrom. A letra "A" na nomeclatura da cultivar indica que foi desenvolvida especialmente para a alimentação humana (JUHÁSZ et al., 2014).

Para hibridações foi realizado dialelo parcial de $6 \times 6$, sem recíproco, perfazendo um total de 36 combinações híbridas, sendo eles BRSMG 800A (TN); BRSMG 790A (TN); TMG1182 RR; M9144 RR; ST820 e BONFIM, utilizados como progênitores masculinos contendo marcador 
fenológico flor roxa e BRS 213 (TN); BRS 216 (TN); GB 874; BRSGO 8660; AMARALINA RR e P98Y70RR, como progenitores femininos contendo marcador fenológico flor branca.

Os cruzamentos foram realizados em dezembro de 2012 em casa de vegetação no Campus Universitário de Gurupi da Universidade Federal do Tocantins. Os cruzamentos foram realizados no período de 5:00 às 8:00 horas, diariamente, após o aparecimento dos primeiros botões florais. Nas plantas receptoras de pólen foram escolhidos botões antes da antese, realizando-se emasculação com auxilio de uma pinça de relógio. As flores doadoras de pólen foram escolhidas nos genitores masculinos quando abertas e na antese, transferindo-se o pólen para o estigma da flor feminina, com auxílio da pinça. Cada botão hibridizado recebeu uma etiqueta com a identificação de seus progenitores.

A população $F 1$ foi cultivada em casa de vegetação havendo seleção precoce fenotípica baseada na cor do hipocótilo, sendo que os híbridos selecionados foram conduzidos no método de condução de população segregante SSD (single seed descent) modificado.

As sementes dos híbridos selecionados (F1 plantio abril de 2013), provenientes dos cruzamentos foram colhidas e identificadas. Em seguida todas as sementes foram cultivadas em campo a fim de obter-se a população segregante F2 em agosto de 2013, F3 em dezembro de 2013 e F4 em junho de 2014.

$\mathrm{Na}$ população segregante $\mathrm{F} 4$ foram selecionados híbridos a campo com a finalidade de identificar através de PCR (Reação da Polimerase em Cadeia), quais plantas obtiveram sucesso na hibridação com a transferência da característica desejada, iniciou as coletas de folhas na fase vegetativa V3 para extração de DNA, as amostras retiradas no campo eram imediatamente levadas para o Laboratório de Manejo Integrado de Pragas da Universidade Federal do Tocantins, todo material vegetal foram lavadas com água destilada e retirado os pecíolos antes da maceração das folhas.

Verifica-se que quanto mais avançado o período vegetativo mais difícil fica a extração de DNA das folhas das plantas, como exemplo tem-se estudos com jaboticabeira feitos por Danner et al. (2011), verificaram que folhas em desenvolvimento apresentaram mais amplificáveis do que folhas desenvolvidas ou partes do caule.

\section{Extração de DNA}

A extração de DNA das amostras foi realizada de acordo com protocolo de Brasileiro e Carneiro (2015). Foram utilizadas, aproximadamente $50 \mathrm{mg}$ de amostra de folhas maceradas em nitrogênio líquido, colocadas em microtubos plásticos de $2 \mathrm{~mL}$, e ressuspendidas em $1 \mathrm{~mL}$ de tampão de extração CTAB 2\% (2\% CTAB, 1,4 M de NaCl 5 M; 100 $\mathrm{mM}$ Tris-HCl $1 \mathrm{M}, \mathrm{pH}$ 8; $20 \mathrm{mM}$ de EDTA $500 \mathrm{mM} ; 0,4 \%$ de $\beta$-mercaptoetanol e água destilada deionizada q.s.q $500 \mathrm{ml}$ ). A seguir, as amostras foram incubadas em banho-maria a 65 ${ }^{\circ} \mathrm{C}$ por aproximadamente $60 \mathrm{~min}$, sendo agitadas levemente a cada $10 \mathrm{~min}$.

Em seguida, foram adicionadas de $0,5 \mathrm{~mL}$ de clorofórmio/álcool isoamílico (CIA) na proporção de 24:1 (v:v), efetuando-se inversão dos tubos seguida de centrifugação à $13000 \mathrm{rpm}$ por $10 \mathrm{~min}$. O sobrenadante foi transferido para novos tubos e o procedimento foi repetido mais uma vez quando houve necessidade. Ao sobrenadante foi adicionado igual volume de isopropanol absoluto resfriado a $-20{ }^{\circ} \mathrm{C}$, promovendo a precipitação do DNA, o qual foi centrifugado e seco ao ar. Os precipitados foram lavados com etanol $75 \%$ por dois minutos e etanol absoluto por mais dois minutos. Após secagem em temperatura ambiente, o DNA foi ressuspendido em $50 \mu \mathrm{L}$ de água milli-Q.

Em todas as extrações, um tratamento com a enzima RNAse se fez necessário. Aos $50 \mu \mathrm{L}$ de DNA em suspensão foi adicionado $2 \mu \mathrm{L}$ de RNAse (2 mg.mL-1), incubando a 37 ${ }^{\circ} \mathrm{C}$ por uma horas. Em seguida, a suspensão de DNA foi armazenada em refrigerador até o momento do uso.

A integridade do DNA foi avaliada por eletroforese em gel de agarose $0,8 \%$ em tampão TBE $1 \times$ x $(5,4 \mathrm{~g}$ de Tris-base; 2,75 g de ácido bórico; 2,0 mL de EDTA pH 8,0 e água destilada e deionizada até completar o volume de $100 \mathrm{~mL}$ ). Para a visualização do DNA, o gel após a eletroforese foi colocado em solução de brometo de etídio na proporção de 0,5 $\mu$ g.mL-1. Após a eletroforese, o gel foi fotografado com aparelho ImageMaster®VDS (Pharmacia Biotech) sob luz ultra-violeta.

\section{Amplificação dos Indel e SNPs}

As reações de amplificação de Indel e SNPs foram feitas em um volume de 10 ou $25 \mu \mathrm{L}$, contendo Tris-HCL 12,5 mM (pH 8,3), KCL 62,5 mM, $\mathrm{MgCl}_{2} 2,5 \mathrm{mM}, 125 \mu \mathrm{M}$ de cada um dos deoxinucleotídios (dATP, dTTP, dGTP e dCTP), 0,2 $\mu \mathrm{M}$ de cada primer (senso e anti-senso), uma unidade da enzima Taq DNA polimerase e $30 \mathrm{ng}$ de DNA. O volume total da reação foi de $25 \mu \mathrm{L}$ quando a separação foi feita em gel de agarose 0,8\% (BRASILEIRO; CARNEIRO, 2015).

As amplificações foram realizadas em termociclador Maxigene Gradient Therm - 1000 utilizada foi, etapa inicial de desnaturação a $94{ }^{\circ} \mathrm{C}$ por $5 \mathrm{~min}$, seguida por 40 ciclos $\left(94{ }^{\circ} \mathrm{C}\right.$ por $45 \mathrm{~s} ; 55{ }^{\circ} \mathrm{C}$ por $45 \mathrm{~s}$; e $72{ }^{\circ} \mathrm{C}$ por $60 \mathrm{~s}$ ) e um período adicional de polimerização a $72{ }^{\circ} \mathrm{C}$, por $4 \mathrm{~min}$, esta programação foi obtida a partir de testes de gradiente de temperatura, com base na programação usada por Silva et al. (2009b). Os fragmentos amplificados foram separados por eletroforese em gel de agarose $0,8 \%$ e tampão TBE $1 \mathrm{X}$ (TrisBorato $90 \mathrm{mM}$, EDTA $2 \mathrm{mM}$ ). Os géis foram corados após a corrida em brometo de etídio $(2 \mu \mathrm{g} / \mathrm{mL})$. Os géis foram fotografados sob luz ultravioleta. Como o objetivo das analises era identificar a presença e a ausência das lipoxigenases 2 e 3, através de marcadores moleculares Indel e SNP (SILVA, 2009b), foram utilizados os seguintes primers (Tabela 1). As PCRs foram realizadas na seguinte sequência: Fez PCR para todas as amostras, com a finalidade de amplificação das amostras de híbridos que contém Lox2 e 3, pois a não amplificação das amostras de híbridos, ou seja ausência de Lox2 e 3 são confirmadas como híbrido TN (característica desejada).

As amostras deste primeiro PCR que não amplificaram ou obtiveram uma amplificação de baixa qualidade, foram feitos um novo teste para todas essas amostras gel de agarose, com posse dos resultados novamente as amostras que não amplificaram a Lox2 e Lox3 perfeitamente foram realizadas um novo PCR, no geral foram realizados uma análises de PCR e mais três retestes para cada amostra, com a finalidade de confirmação e maior acurácia dos resultados, pois o que se busca nestas análises são a ausência dos genes, ou seja ausência de amplificação. Os primes utilizados nas análises de PCR foram todos testados anteriormente para verificação de sua funcionalidade pela PCR, todos confirmaram com resultados claros a partir de cultivares de soja normal 
(testemunhas), todos com a programação do termociclador citado acima, desta forma para a Lox3, foi usado para todas as amostras apenas o primer Lox3.4 (Tabela 1 e Figura 1), devido sua quantidade não houve necessidade de usar os outros primers.

Tabela 1. Pares de primers utilizados para a amplificação de fragmentos do gene das lipoxigenases 2 e 3 de soja

\begin{tabular}{lclc}
\hline Primer & Direção & Sequencia $\left(5^{\prime} \rightarrow 3\right.$ ') & Tamanho do amplicon $(\mathrm{pb})$ \\
\hline \multirow{2}{*}{ LOX2 } & $\mathrm{R}$ & TTGCAAACAAAGCGAATGGTT & 804 \\
& $\mathrm{~F}$ & GGTGTCGGGAATCCTGAACA & 571 \\
LOX3.2 & $\mathrm{R}$ & TGGATGAAGTAATTAGGAAAAATAAGAAAG & 367 \\
& $\mathrm{~F}$ & TTATAAAAAGAGAGTAAGAAAATGTTGTGG & 529 \\
LOX3.4 & $\mathrm{R}$ & CTCATATAACAAATAATGAAGACACACAAG & \\
& $\mathrm{F}$ & AATTATTGGTCAAGGTCTCGACTTAGTT & \\
LOX3.9 & $\mathrm{R}$ & ATATTATTTCGTTGAGAAAATGTATACCAA & \\
& $\mathrm{F}$ & GATCATACTAGTCAAATAACCAAAGAACAC &
\end{tabular}

Fonte: SILVA (2009b)

Figura 1. Esquema de anelamento dos 14 pares de primers amplificadores do gene Lox3. Em destaque os primers Lox3.2, Lox3.4 e Lox3.9 utilizados nas PCR para identificação das plantas Triplo Nulo

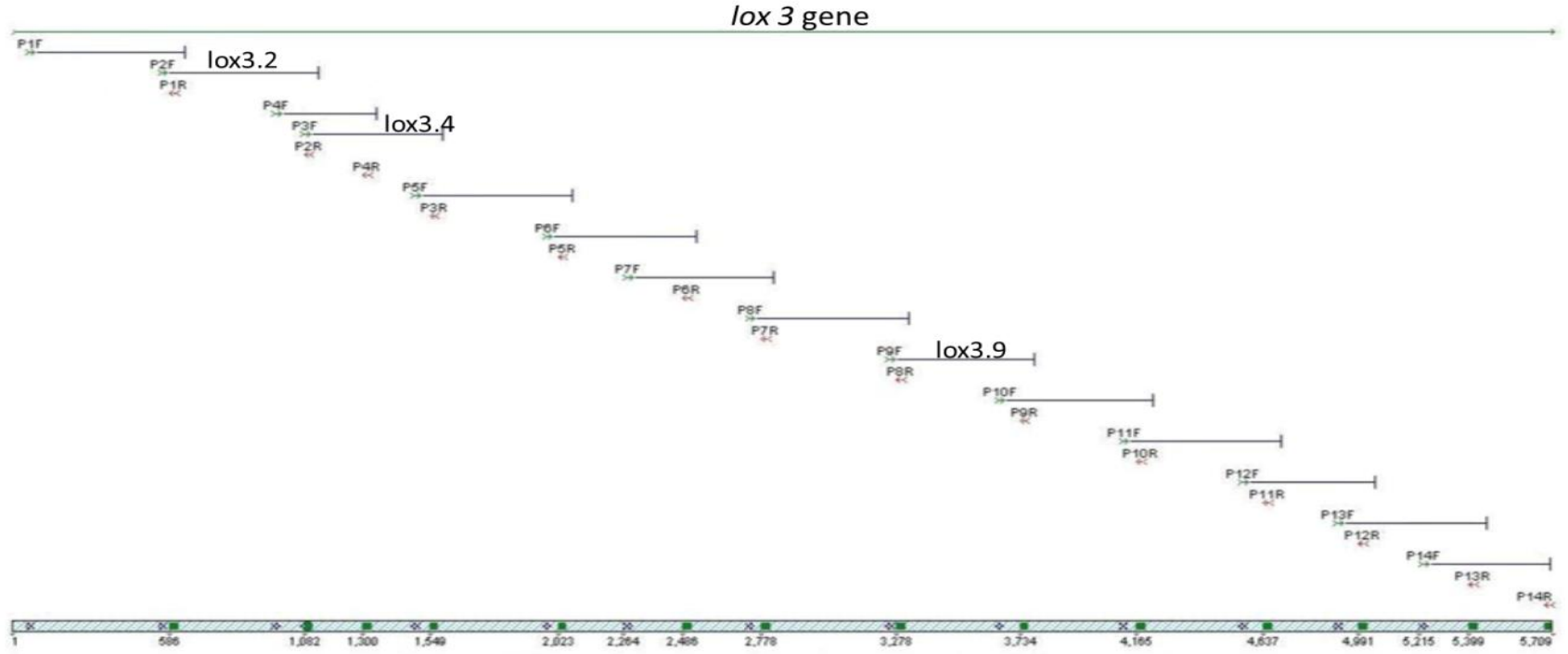

Fonte: Silva (2009b)

\section{RESULTADOS E DISCUSSÃO}

Das trinta e seis possibilidades de cruzamento existentes no dialelo, foram expostos neste trabalho apenas as combinações envolvendo progenitores $\mathrm{TN}$, com isso das vinte possibilidades de cruzamento, obteve-se sucesso apenas em doze (Tabela 2), dos quais seguiram no programa de melhoramento.
Dos cruzamentos envolvendo progenitores $\mathrm{TN}$, os que obtiveram os melhores resultados em porcentagem de sucesso na hibridação foram: BRSMG 800A (TN) X BRS 213 (TN); BRSMG 790A (TN) X AMARALINA RR e BONFIM X BRS 216 (TN) (Tabela 2), ambos cruzamentos com vinte e cinco por cento, podendo assim inferir que os progenitores envolvidos nestes cruzamentos, possam ser usados em novos grupos de dialelos que busquem o melhoramento de soja tipo alimento humano.

Tabela 2. Relação dos cruzamentos, porcentagem de sucesso na hibridação dentro dos cruzamentos e numero de híbridos selecionados de cada cruzamento

\begin{tabular}{llll}
\hline Progênitores Masculino & Progênitores Feminino & \% Hibridação & N. de Plantas Selecionadas \\
\hline BRSMG 800A (TN) & BRS 213 (TN) & 25 & 14 \\
BRSMG 800A (TN) & BRS 216 (TN) & 20 & 6 \\
BRSMG 800A (TN) & P98Y70RR & 12 & 16 \\
BRSMG 800A (TN) & BRSGO 8660 & 15 & 37 \\
BRSMG 790A (TN) & GB 874 & 16 & 9 \\
BRSMG 790A (TN) & AMARALINA RR & 25 & 15 \\
BRSMG 790A (TN) & BRSGO 8660 & 23 & 32 \\
BRSMG 790A (TN) & P98Y70RR & 16 & 12 \\
TMG1182 RR & BRS 216 (TN) & 16 & 1 \\
M9144 RR & BRS 216 (TN) & 16 & 25 \\
ST820 & BRS 216 (TN) & 16 & 2 \\
BONFIM & BRS 216 (TN) & 25 & 171 \\
\hline Total & & & \\
\hline
\end{tabular}


De acordo com Narvel et al. (1998) confirma que a ausência das três isoenzimas de lipoxigenases não influenciam no desempenho da soja para caracteristicas agronômicas e composição da semente. Desta forma a retirada destas três lipoxigenases a partir de melhoramento genetico não trazem prejuizos a cultura.

Nas populações F2 e F3 houve segregação, dentro dessas segregações foi constatado sementes de tegumentos amarelo, verde, marron e preto, mas com a seleção em F4 de cento e setenta e um híbridos (Tabela 3), verificou-se que dentre todos estes híbridos nenhum foi selecionado para seguir no programa de melhoramento com coloraçao de teguemento verde, marron ou preto.
Também demonstra a quantidade de híbridos selecionadas dentro de cada cruzamento (Tabela 3), estes híbridos foram selecionadas de acordo com caracteristicas agronômicas favoraveis as condições edafoclimáticas do cerrado (Sul do Estado do Tocantins), arquitetura de plantas, altura de plantas e sanidade, outro fator importantissimo usado como criterio de seleção foi o periodo juvenil longo, de acordo com Spehar et al. (2014), seleção de cultivares com fase vegetativa prolongada, com alelos de período juvenil longo, induzem a planta obter maiores altura e ter florescimento mais tardio, resultando em plantas com maiores biomassa e produtividade de grãos.

Tabela 3. Relação dos cruzamentos, porcentagem de sucesso nos cruzamentos (híbridos), numero identificador dos híbridos com ausência Lox2, porcentagem de híbridos selecionadas no cruzamento com ausência da Lox2, numero identificador dos híbridos com ausência das Lox3, porcentagem de híbridos selecionados no cruzamento com ausência da Lox3, numero identificador dos híbridos Triplo Nulo (TN) e porcentagem de híbridos selecionadas no cruzamento identificadas como TN

\begin{tabular}{|c|c|c|c|c|c|c|}
\hline Cruzamentos & Ausência LOX2 & $\begin{array}{l}\% \text { Ausência } \\
\text { de Lox } 2\end{array}$ & Ausência Lox3 & $\begin{array}{l}\text { \% Ausência } \\
\text { de Lox3 }\end{array}$ & híbridos TN & $\begin{array}{l}\text { \% Híbrido } \\
\text { TN }\end{array}$ \\
\hline $\begin{array}{l}\text { BRSMG 800A (TN) x } \\
\text { BRS } 213(\mathrm{TN})\end{array}$ & $1,2,3,4,8,10$ e 13 & 50 & $1,3,4$ e 13 & 28 & $1,3,4$ e 13 & 28 \\
\hline $\begin{array}{l}\text { BRSMG 790A }(\mathrm{TN}) \mathrm{x} \\
\text { GB } 874\end{array}$ & $\begin{array}{l}15,16,17,18,19,20 \\
\text { e } 21\end{array}$ & 77 & $15,16,18$ e 21 & 44 & $\begin{array}{l}15,16,18 \mathrm{e} \\
21\end{array}$ & 44 \\
\hline $\begin{array}{l}\text { TMG1182 RR x BRS } \\
216(\mathrm{TN})\end{array}$ & $0^{*}$ & 0 & $0 *$ & 0 & $0 *$ & 0 \\
\hline $\begin{array}{l}\text { BRSMG 790A (TN) x } \\
\text { AMARALINA RR }\end{array}$ & $0 *$ & 0 & $0 *$ & 0 & $0^{*}$ & 0 \\
\hline $\begin{array}{l}\text { M9144 RR x BRS } 216 \\
(\mathrm{TN})\end{array}$ & $\begin{array}{l}43,44,52,54,55,56, \\
59,70 \text { e } 71\end{array}$ & 36 & $49,52,70$ e 71 & 16 & 52,70 e 71 & 12 \\
\hline $\begin{array}{l}\text { BRSMG 800A }(\mathrm{TN}) \mathrm{x} \\
\text { BRS } 216(\mathrm{TN})\end{array}$ & $74,75,76$ e 79 & 66 & 74 e79 & 33 & 74 e 79 & 33 \\
\hline $\begin{array}{l}\text { BRSMG 790A (TN) x } \\
\text { BRSGO } 8660\end{array}$ & $\begin{array}{l}80,82,83,87,90,92 \\
93,94,98 \text { е } 99\end{array}$ & 31 & $\begin{array}{l}80,82,83,87 \\
92,93,94,96 \\
98,99 \text { e } 101\end{array}$ & 34 & $\begin{array}{l}80,82,83 \\
87,92,93 \\
94,98 \text { e } 99\end{array}$ & 28 \\
\hline ST820 x BRS $216(\mathrm{TN})$ & $0 *$ & 0 & $0^{*}$ & 0 & $0^{*}$ & 0 \\
\hline $\begin{array}{l}\text { BONFIM x BRS } 216 \\
\text { (TN) }\end{array}$ & $0 *$ & 0 & $0 *$ & 0 & $0 *$ & 0 \\
\hline $\begin{array}{l}\text { BRSMG 800A (TN) x } \\
\text { P98Y70RR }\end{array}$ & $\begin{array}{l}117,118,127,128 \\
130 \text { e } 131\end{array}$ & 37 & 117 e 118 & 12 & 117 e 118 & 12 \\
\hline $\begin{array}{l}\text { BRSMG 790A }(\mathrm{TN}) \mathrm{x} \\
\text { P98Y70RR }\end{array}$ & $\begin{array}{l}133,134,135,137, \\
138,139,140,141, \mathrm{e} \\
142\end{array}$ & 75 & 134,137 e 139 & 25 & $\begin{array}{l}134,137 \mathrm{e} \\
139\end{array}$ & 25 \\
\hline $\begin{array}{l}\text { BRSMG 800A }(\mathrm{TN}) \mathrm{x} \\
\text { BRSGO } 8660\end{array}$ & $\begin{array}{l}144,145,146,147, \\
149,152,153,154, \\
155,156,157,159, \\
160,161,162,163, \\
165,166 \text { e } 177\end{array}$ & 51 & $\begin{array}{l}145,149,154 \\
156,157,161 \\
\text { e177 }\end{array}$ & 19 & $\begin{array}{l}145,149 \\
154,156 \\
157,161 \mathrm{e} \\
177\end{array}$ & 19 \\
\hline TOTAL & 71 & 41,5 & 37 & 22 & 34 & 20 \\
\hline
\end{tabular}

Fez-se extração de DNA de todas as amostras, foram confirmadas por análise de eletroforese em gel de agarose a $0,8 \%$, quando não houve sucesso na primeira extração foram repetidas as extrações até o objetivo ser alcançado, possivelmente a dificuladade de extrair DNA esta relacionado a passagem das plantas selecionadas do periodo vegetativo para o reprodutivo, pois os tecidos foliares ficam mais fibrosos.

Este rigor nas extrações de DNA deve-se a extrema importância de obter resultados com maior confiança possível, pois se não houver DNA na amostra ao ser feito
PCR não haverá amplificação, confirmando esta amostra como híbrido TN.

O PCR foi a técnica laboratorial usada na amplificações das regiões do DNA catalizadas pela enzima DNA polimerase. Foram utilizados primers específicos para amplificação da região das lipoxigenases 1 e 2 (Dois genes estão situados no mesmo cromossomo a uma distância menor que $50 \mathrm{cM}$ (centimorgan) e pelos primers da lipoxigenase 3 . Estes primers foram construídos a partir de marcadores moleculares INDEL e SNP (SILVA, 2009b).

Os resultados obtidos da amplificação foram vizualizados por eletroforese em gel de agarose a $0,8 \%$, a 
PCR foi repetida para todas as amostras afim de obter resultados que confirmassem com maior clareza possivel o sucesso ou não da amplificação do DNA das plantas. Esta busca por maior exatidão dos produtos da amplificação é devido os resultados da não amplificação serem identificados como plantas $\mathrm{TN}$, as quais seguirão no programa de melhoramento de soja alimentação humana.

Foram realizadas PCR para todas as amostras, resultanto em, setenta e uma amostras que não amplificaram a região da Lox2 e, trinta e sete a região da Lox3, a partir desta combinação de resultados obteve-se trinta e quatro híbridos identificados atraves de confirmação de DNA como Triplo Nulo (TN) (Tabela 3). Observa-se que o cruzamento BRSMG 790A (TN) X GB874, foi o que obteve a maior porcentagem de transferência da caracteristica genética ausência de lox2 $(77 \%)$ e lox3 (44\%), resultando na maior porcentagem de híbridos TN (44\%) (Tabela 3).

Com estes resultados pode-se resaltar que o uso destes progenitores, principalmente o BRSMG 790A (TN), em cruzamento ou retrocruzamentos com a finalidade de obter híbridos $\mathrm{TN}$ e de grande importancia, pois se mostraram promissores na transferência da caracteristica desejada, observa-se quase o dobro de híbridos com ausência da Lox2 em relação a Lox3 (Tabela 3).

De acordo com Kim et al. (2004), a região intrônica do gene da lipoxigenase 2 corresponde a uma seqüência de 804 nucleotídeos. A lipoxigenase 3 é uma região composta por uma seqüência de 5709 nucleotídeos, disponível no Genbank (National Center for Biotechnology Information - NCBI) com o número de acesso X06928.1. Essa seqüência contém: uma região 3' transcrita e não traduzida (UTR- untranslated region), a região promotora, 8 íntrons, 9 éxons, e a região 5' UTR (SILVA, 2009b). Partindo destas informações pressupõe-se, provavelmente, que o gene codificador da expressão da Lox 2 por ser um gene menor é mais facilmente transferido comparado com a Lox3, justificando esta grande diferença de transferência de um gene comparado ao outro.

Encontram-se os geis de eletroforese obtidos pela amplificação das regiões das lipoxigenases 2 e 3 (Figura 2). Nelas é possivel observar claramente o tamanho de cada região amplificada (Figura $2 \mathrm{~A}$ e $2 \mathrm{~B}$ ) e o comparativo do tamanho das regiões das lipoxigenades 2 e 3 (Figura 2C).

Figura 2. Análise eletroforética, em gel de agarose $0,8 \%$, do produto de amplificação dos primers LOX2 e LOX3.4. (A) três primeiras canaletas são fragmentos amplificados de plantas normais, com presença da LOX2 e as três ultimas canaletas de plantas TN, ausência de LOX2. (B) três primeiras canaletas são fragmentos amplificados de plantas normais, com presença da LOX3 e as três ultimas canaletas de plantas TN, ausência de LOX3. (C) três primeiras canaletas são fragmentos amplificados de plantas normais com presença de LOX2 e as três ultimas com presença de LOX3
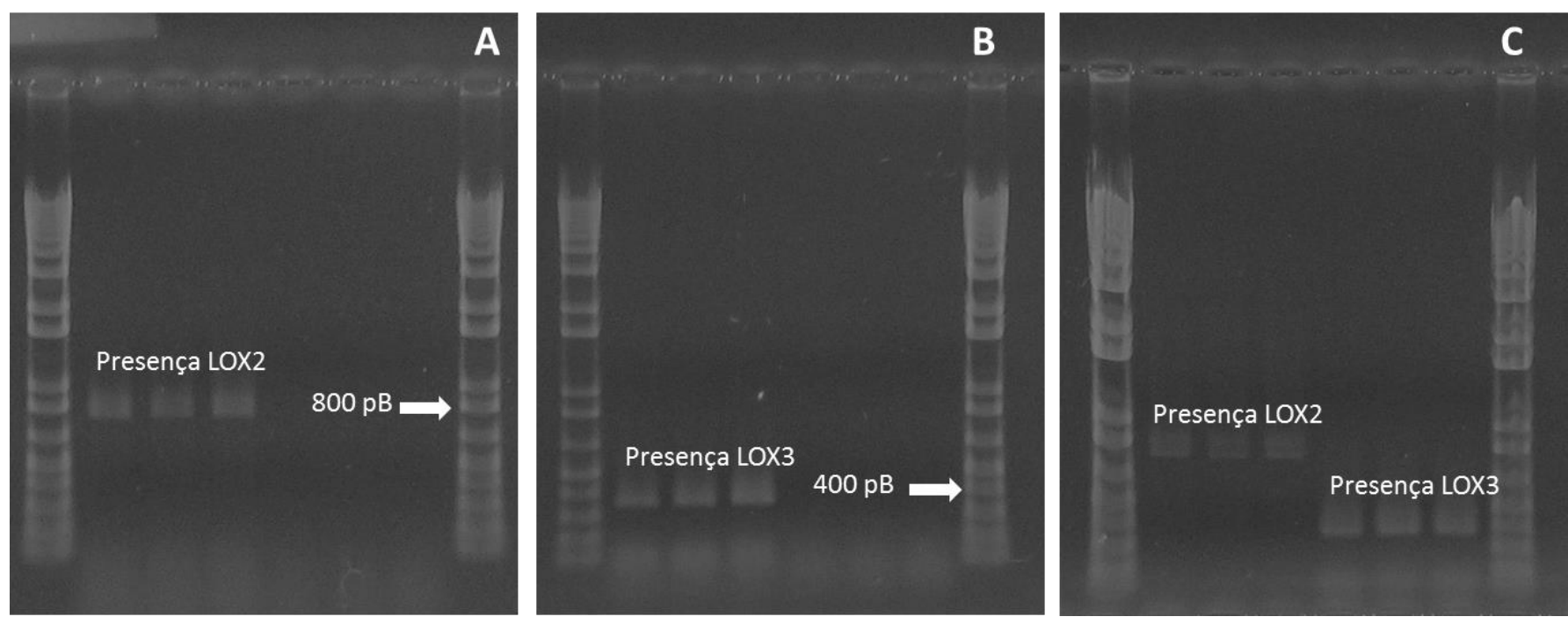

O tamanho dos fragmentos amplificados conferiram com o esperado, como pode ser visto nas figuras $2 \mathrm{~A}, 2 \mathrm{~B}$ e $2 \mathrm{C}$. A Lox2 esta próximo a $800 \mathrm{pB}$ e a Lox3 próximo a $400 \mathrm{pB}$, estes resultados corroboram com os dados apresentados na Tabela 1 .

Os híbridos 1, 3, 4, 13, 15, 16, 18, 21, 52, 70, 71, 74, 79, $80,82,83,87,92,93,94,98,99,117,118,134,137,139$, $145,149,154,156,157,161$ e 177 foram selecionadas e identificadas com triplo nulo, eles serão testadas nos ensaios preliminares e finais de competição.

\section{CONCLUSÕES}

A maior porcentagem de híbridos TN foi obtida no cruzamento BRSMG 790A (TN) X GB874.

Os primers amplificadores das regiões Lox2 e Lox3 confirmaram como ferramenta essencial em programa de melhoramento genético de soja para alimentação humana.
Foram selecionados 34 híbridos TN com características agronômicas desejadas.

\section{REFERÊNCIAS}

ASTADI, I. R.; ASTUTI, M.; SANTOSO, U.; NUGRAHENI, P. S. In vitro antioxidant activity of anthocyanins of black soybean seed coat in human low density lipoprotein (LDL). Food Chemistry, v.112, p.659663, 2009.

BRASILEIRO, A. C. M.; CARNEIRO, V. T. C. Manual de transformação genética de plantas. 2. ed. rev. ampl. Embrapa, Brasília, Brasil, 2015. 453p.

CHOI, I. Y.; HYTEN, D. L.; MATUKUMALLI, L. K.; SONG, Q. J.; CHAKY, J. M.; QUIGLEY, C. V.; CHASE, K.; LARK, K. G; REITER, R. S.; YOON, M. S.; Hwang, E. Y.; Yi, S. I.; Young, N. D.; SHOEMAKER, R. C.; TASSELL, C. 
P. V.; SPECHT, J. E.; CREGAN, P. B. A soybean transcript map: gene distribution, haplotype and single nucleotide polymorphism analysis. Genetics, Austin, v.176, p.685-696, 2007.

DANNER, M. A.; SASSO, S. A. Z.; BITTENCOURT, J. V. M.; CITADIN, I.; SACHET, M. R. Proposta de protocolo para extração de DNA de jabuticabeira. Ciência Florestal, Santa Maria, v.21, p.363-367, 2011.

DANTAS, M. I. S.; SILVA, M. G.; PINTO, C. R. R.; PEREIRA, C. A. S. P.; MINIM, V. P. R.; BITTENCOURT, M. C. B. Farinhas de soja sem lipoxigenase agregam valor sensorial em bolos. Revista Ceres, Viçosa, v.57, n.2, p.141144, 2010.

DUFFY, C.; PEREZ, K.; PARTRIDGE, A. Implications of phytoestrogen intake for breast cancer. CA Cancer J Clinical, v.57, p.260-277, 2007.

FARIA, A. P.; FONSECA JÚNIOR, N. S. F.; DESTRO, D.; FARIA, R. T. Ganho genético na cultura da soja. Genetic gain in soybean crop, Semina: Ciencias Agrárias, Londrina, v.28, n.1, p.71-78, 2007.

JUHÁSZ, A. C. P.; CIABOTTI, S.; PÁDUA, G. P.; FAVORETO, L.; JESUS, A. M. S.; FRONZA, V. Melhoramento de Soja pra Alimentação Humana. Informe Agropecuário, Belo Horizonte, v.35, p.39-45, 2014.

KIM, M. Y.; HA, B. K.; JUN, T. H.; WANG, E. Y.; VAN, K.; KUK, Y.; LEE, S. Single nucleotide polymorphism discovery and linkage mapping of lipoxygenase-2 gene (Lx 2) in soybean. Euphytica, Philadelphia, v.135, p.169-177, 2004.

KIM, Y.S.; MOOM, J.K.; CHO, J.H.; KIM, H.T.; PARK, K.Y.; KIM, S.J. Improvement of special characters on three elite soybean cultivars by markers-assisted selection. Treatment Of Crop Science, Madison, v.7, p.197-210, 2006.

MACHADO, F. P. P.; QUEIRÓZ, J. H.; OLIVEIRA, M. G. A.; PIOVESAN, N. D.; PELUZIO, M. C. G.; COSTA, N. M. B.; MOREIRA, M. A. Effects of heating on protein quality of soybean flour devoid of Kunitz inhibitor and lectin. Food Chemistry, v.107, p.649-655, 2008.

NARVEL, J. M.; FEHR, W. R.; WELKE, G. A. Agronomic and seed traits of soybean lines lacking seed lipoxygenases. Crop Science, Madison, v.38, p.926-928, 1998.

OLIVEIRA, M. A.; CARRÃO PANIZZI, M. C.; MANDARINO, J. M. G.; LEITE, R. S.; CAMPOS FILHO, P. J.; VICENTINI, M. B. Quantificação dos teores de açúcares, oligossacarídeos e amido em genótipos/cultivares de soja (Glycine $\max (\mathrm{L})$ Merril) especiais utilizados na alimentação humana. Brazilian Journal of Food Technology, Campinas, v.13, p.23-29, 2010.

SANTOS, E. R.; BARROS, H. B.; CAPONE, A.; FERRAZ, E. C.; SANTOS, A. F.; FIDELIS, R. R. Divergência entre genótipos de soja, cultivados em várzea irrigada. Revista Ceres, Viçosa, v.58, n.6, p.755-764, 2011.
SILVA, C. O.; ANDRADE, G. F.; DANTAS, M. I. S.; COSTA, N. M. B.; PELUZIO, M. C. G.; FONTES, E. A. F.; MARTINO, H. S. D. Influência do processamento na qualidade proteica de novos cultivares de soja destinados à alimentação humana. Revista Nutrição, Campinas, v.23, p.389-397, 2010.

SILVA, D. F. Identificação e validação de marcadores moleculares Indel e SNP para lipoxigenases de sementes de soja. Viçosa, Universidade Federal de Viçosa, 2009b. 78p. Dissertação Mestrado em Bioquímica Agrícola.

SILVA, C. E.; CARRÃO-PANIZZI, M. C.; MANDARINO, J. M. G.; LEITE, R. S.; MÔNACO, A. P. A. Isoflavone contents of whole soybeans and their components, obtained from different cultivars (Glycine max (L.) Merrill). Brazilian Journal of Food Technology, Campinas, v.15, p.150-156, 2012.

SILVA, J. B.; CARRÃO-PANIZZI, M. C.; PRUDÊNCIO, S. $\mathrm{H}$. Chemical and physical composition of grain type and food type soybean for food processing. Pesquisa Agropecuária Brasileira, Brasília, v.44, n.7, p.777-784, 2009a.

SPEHAR, C. R.; FRANCISCO, E. R.; PEREIRA, E. A. Yield stability of soybean cultivars in crop seasons and sowing dates at low latitude Brazilian Savannah Highlands. Journal of Agricultural Science, Cambridge, v.153, p.1059-1068, 2014.

VASCONCELOS, E. S.; REIS, M. S.; SEDIYAMA, T.; CRUZ, C. D. Produtividade de grãos, adaptabilidade e estabilidade de genótipos de soja de ciclos precoce e médio. Semina, Londrina, v.36, n.3, p.1203-1214, 2015.

WANG, Y. J.; SHEEN, L. Y.; CHOU, C. C. Storage effects on the content of anthocyanin, mutagenicity and antimutagenicity of black soybean koji. LWT-Food Science Technology, Taiwan, v.43, p.702-707, 2010. 